\title{
Rare vardenafil-associated Stevens-Johnson syndrome: toxic epidermal necrolysis
}

\author{
Katerina Grafanaki (D) ,' Spyridon Lygeros, ${ }^{2}$ Eleutheria Maria Vryzaki, \\ Sophia Georgiou ${ }^{1}$
}

'Department of Dermatology, Panepistemio Patron Tmema latrikes, Patras, Achaea, Greece 2Ear, Nose, Throat Department, University General Hospital of Patras Greec, Patras, Greece

\section{Correspondence to}

Dr Katerina Grafanaki; grafanaki@med.upatras.gr

Accepted 27 January 2022

\section{DESCRIPTION}

A previously healthy 52-year-old single Caucasian man presented with Stevens-Johnson syndrome (SJS) toxic epidermal necrolysis (TEN): extensive mucocutaneous damage characterised by blistering and epithelial shedding on torso, mouth and genitalia following uptake of $20 \mathrm{mg}$ vardenafil hydrochloride over the counter (OTC), two times in 5 days, 12 days prior. Three days before hospital presentation, he developed a febrile $\left(38,5^{\circ} \mathrm{C}\right)$ influenza-like prodrome with runny nose, malaise and cough. Two days later, he noted the appearance of red-purple macules on the extremities (figure 1A), mouth (lips, palate, tongue, buccal mucosa) (figure 1B) and genitals that turned into blisters; detachment of the skin and mucous membranes and painful erosions (figure 1C). $\mathrm{He}$ presented with persistent hiccups (3 days); however, otorhinolaryngology consultation was impossible to solicit. The patient's history was free from medications, and drug or other allergies.

Nikolsky sign was positive, and no lymphadenopathy was notable. Systemic examination was unremarkable. Tests for SARS-CoV-2, venereal disease research laboratory test (VDRL), mycoplasma, herpes virus family (HSV1/2, VZV, CMV, EBV, HHV6) and human immunodeficiency virus $(1 \& 2)$ were all negative. A skin biopsy confirmed SJS. Laboratory examination revealed elevation of non-specific inflammatory markers: C-reactive protein $(\mathrm{CRP}): 19 \mathrm{mg} / \mathrm{dL}(<0.5)$, erythrocyte sedimentation rate (ESR): 95 (0-10), ferritin: $2624 \mathrm{ng} / \mathrm{mL}$ (16-323), Antinuclear Antibody

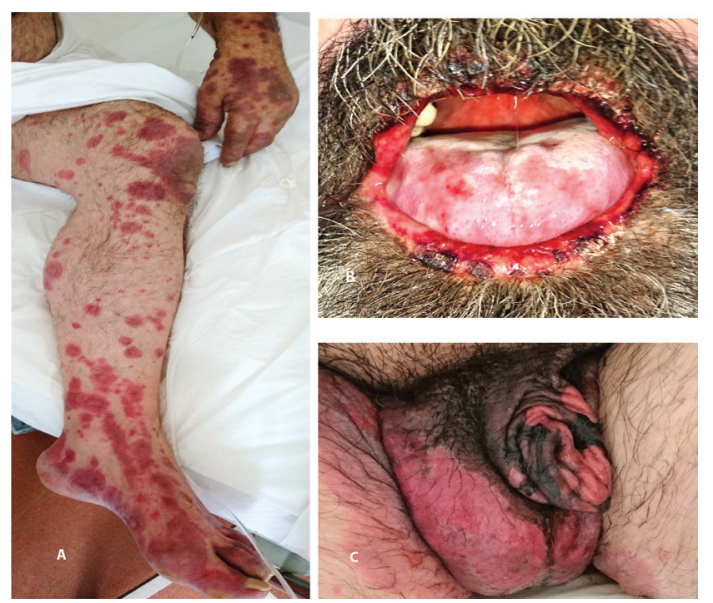

Figure 1 (A) Atypical red-purple macules and dusky erythema on the extremities. (B) Erosive cheilitis, extensive mucosal erosions of the buccal and labial mucosa. (C) Mucositis of the genitalia and confluent involvement of the scrotum and the glans penis.
(ANA): negative, $\mathrm{C} 3$ and $\mathrm{C} 4$ within normal range. $\mathrm{A}$ team approach had been implemented and he received supportive care, monitoring, prophylactic therapy (antibiotics and antivirals), systemic corticosteroids, metoclopramide and careful protection of the skin and mucosa. ${ }^{1}$ He was discharged 3 weeks later. Despite the severity of his condition, he only revealed the aetiologically causative drug 7 days inpatient (Naranjo score $=7$ 'probable'). ${ }^{2}$ Given the clinical features, the temporal association with the drug and the patient's free medical history, vardenafil-induced SJS/TEN was diagnosed.

Phosphodiesterase-5 inhibitors (PDE5i), such as vardenafil, are used in the treatment of erectile dysfunction. ${ }^{3}$ Adverse drug reactions (ADRs) are scarce, however, ocular complications, hearing loss and fixed drug eruption have been reported. ${ }^{4-6}$

Severe cutaneous adverse reactions (SCARs) are uncommon and potentially life-threatening immunemediated ADRs, with diverse clinical phenotypes, including SJS/TEN. At least 200 drugs have been reported to be associated with the onset of the disease, including nonsteroidal anti-inflammatory drugs, sulfa-derived medications, lactam antibiotics and anticonvulsants.

SCARs like SJS/TEN are type IV delayed-type hypersensitivity reactions, mediated either by direct cytotoxicity of CD $8+\mathrm{T}$ cells or by release of CD4 + derived cytokines via antigen presenting cells, such as macrophages and dendritic cells.? Macrophages are major cellular producers of ferritin and remarkable serum ferritin was observed in the patient, in the setting of ongoing inflammation, together with other acute-phase reactants, such as ESR and CRP. ${ }^{8}$

Sexual and reproductive health is a significant public health issue, and the COVID-19 quarantine had an impact in mental and physical health and to the best of our knowledge, this is the first vardenafil-induced SJS case. ${ }^{9}$ Recently, drug eruption with eosinophilia and systemic symptoms has been reported, and an increase in PDE5i concentrations was detected in wastewater. ${ }^{10}$ Therefore, a possibility of an increased consumption

\section{Patient's perspective}

COVID-19 quarantine made me feel uncertain of what the future will hold. Recently engaged, I was stressing to maintain an active sex-life during selfisolation, since we spent so much time together. A friend advised me of an OTC "help". Unfortunately, not only did this choice end to a severe side effect, but it has forever scarred me. 


\section{Learning points}

- Phosphodiesterase-5 inhibitors (PDE5i), such as vardenafil, are used in the treatment of erectile dysfunction, either over the counter or under prescription and are generally well tolerated.

- Stevens-Johnson syndrome-toxic epidermal necrolysis overlap represents an extremely rare adverse effect of vardenafil.

- The COVID-19 pandemic had an impact in physical and mental health with a possible PDE5i uptake increase.

requires pharmacovigilance for early management in probable upcoming SCARs.

Contributors All authors contributed equally. KG, EMV, SL and SG contributed in the clinical management and therapeutics of the patient as well as in the conceptualisation and writing of the manuscript.

Funding The authors have not declared a specific grant for this research from any funding agency in the public, commercial or not-for-profit sectors.

Competing interests None declared.

Patient consent for publication Consent obtained directly from patient(s)

Provenance and peer review Not commissioned; externally peer reviewed.

Case reports provide a valuable learning resource for the scientific community and can indicate areas of interest for future research. They should not be used in isolation to guide treatment choices or public health policy.
ORCID ID

Katerina Grafanaki http://orcid.org/0000-0002-6569-1928

\section{REFERENCES}

1 Lerch M, Mainetti C, Terziroli Beretta-Piccoli B, et al. Current perspectives on Stevens-Johnson syndrome and toxic epidermal necrolysis. Clin Rev Allergy Immunol 2018;54:147-76

2 Naranjo CA, Busto U, Sellers EM, et al. A method for estimating the probability of adverse drug reactions. Clin Pharmacol Ther 1981;30:239-45.

3 Hong Y, Lee I, Tae B, et al. Contribution of sewage to occurrence of phosphodiesterase-5 inhibitors in natural water. Sci Rep 2021;11:9470.

4 Laties AM. Vision disorders and phosphodiesterase type 5 inhibitors: a review of the evidence to date. Drug Saf 2009;32:1-18.

5 Snodgrass AJ, Campbell HM, Mace DL, et al. Sudden sensorineural hearing loss associated with vardenafil. Pharmacotherapy 2010;30:112

6 Beer K. A challenging eruption. J Drugs Dermatol 2012;11:1494-5.

7 Cheng L. Current pharmacogenetic perspective on Stevens-Johnson syndrome and toxic epidermal necrolysis. Front Pharmacol 2021;12:588063.

8 Kernan KF, Carcillo JA. Hyperferritinemia and inflammation. Int Immunol 2017;29:401-9.

9 Tang K, Gaoshan J, Ahonsi B, et al. Sexual and reproductive health (SRH): a key issue in the emergency response to the coronavirus disease (COVID-19) outbreak. Reprod Health 2020;17:59.

10 Gupta SK, Sushantika S, Abdelmaksoud A. Sildenafil-induced hypersensitivity syndrome/drug reaction with eosinophilia and systemic symptoms: case report with review. Dermatol Ther 2020;33:e13826.

Copyright 2022 BMJ Publishing Group. All rights reserved. For permission to reuse any of this content visit

https://www.bmj.com/company/products-services/rights-and-licensing/permissions/

BMJ Case Report Fellows may re-use this article for personal use and teaching without any further permission.

Become a Fellow of BMJ Case Reports today and you can:

- Submit as many cases as you like

- Enjoy fast sympathetic peer review and rapid publication of accepted articles

- Access all the published articles

Re-use any of the published material for personal use and teaching without further permission

Customer Service

If you have any further queries about your subscription, please contact our customer services team on +44 (0) 2071111105 or via email at support@bmj.com.

Visit casereports.bmj.com for more articles like this and to become a Fellow 